\title{
STUDENTS' PERCEPTIONS TOWARDS PRAISE AS CLASSROOM COMMUNICATIVE REINFORCING DEVICE
}

\author{
Vu Van Tuan \\ Hanoi Law University
}

\begin{abstract}
Fostering an active learning environment for students to become motivated and engaged in learning is essential in terms of both teaching and classroom management. The concerns how evaluative feedback used as praise hereafter affects students' motivation in the classroom depend on the messages students receive from their teachers. This research was conducted on the effects of six different kinds of teachers' praise on students' cognition, involving 50 students and five instructors from three universities in Hanoi. The study was based on the case study with the data collected through observation and semi-structured interviews. The findings revealed that six types of teachers' praise were perceived differently by students. The results would benefit educators to create an active and innovative setting for learning and teaching success.
\end{abstract}

Keywords: Praise; communicative reinforcing device; perceptions; cognition.

Received: 29/10/2019; Revised: 24/02/2020; Published: 28/02/2020

\section{CẢM NHẬN CỦA SINH VIÊN ĐỐI VỚI LỜI KHEN NHƯ LÀ CÔNG CỤ TĂNG CƯờnG SỰ GIAO TIÊP TRONG LỚP HỌC}

\author{
Vũ Văn Tuấn \\ Trưòng Đại học Luật Hà Nội
}

\section{TÓM TẮT}

Tạo môi trường tích cực cho sinh viên được khuyến khích, kích thích tham gia vào học tập là rất quan trọng đối với việc giảng dạy và quản lý lớp học. Mối quan tâm là làm thế nào để các lời khen đánh giá sinh viên thúc đẩy họ tham gia vào quá trình học phụ thuộc vào tín hiệu mà sinh viên nhận được từ giảng viên. Nghiên cứu đánh giá tầm ảnh hưởng của 6 loại khen khác nhau của giảng viên tác động đến nhận thức của sinh viên. Nghiên cứu này bao gồm 50 sinh viên và 5 giảng viên ở 3 trường đại học tại Hà Nội. Dữ liệu thu thập thông qua nghiên cứu tình huống dựa trên quan sát lớp học và phỏng vấn bán cấu trúc. Kết quả của nghiên cứu chỉ ra rằng sinh viên cảm nhận các lời khen là hoàn toàn khác nhau. Kết quả của nghiên cứu mang lại ích lợi cho người làm giáo dục tạo ra một môi trường năng động và sáng tạo phục vụ cho sự thành công của việc giảng dạy.

Từ khoá: Lời khen; công cu tăng cương sụ giao tiếp; sụ cảm nhận; nhận thức.

Ngày nhận bài: 29/10/2019; Ngày hoàn thiện: 24/02/2020; Ngày đăng: 28/02/2020

Email: vuvantuanphd@gmail.com

DOI: https://doi.org/10.34238/tnu-jst.2020.03.2271 


\section{Introduction}

Teacher praise plays a vital part in terms of encouragement and motivation for communication transaction in the classroom. In educational settings, being noticed and appreciated for their good behaviours, students actively participate in learning activities. In fact, the strength of teacher praise positively influences students' intrinsic motivation to learn [1], [2], promotes positive student behavior [3], [4], fosters their academic engagement and achievement [5], [6], and helps to build self - esteem [7] as well as enhances a teacher-student relationship [8]. Actually, giving praise has been reported to be one of the most long-recognized and essential skills for language teachers and the strategies, teachers also find it the easiest to implement in the classroom [9].

OALD9 [10] defines the term "praise" as a word that shows approval of or admiration for somebody/something. Similarly, Canter \& Canter [11] regard praise as positive recognition, sincere and meaningful attention for behaving according to expectations. It can be said that praise is regarded as positive reinforcement, as a rewarding stimulus or as an important device that teachers should frequently use to activate, and motivate desirable behaviours in some actions. It is necessary to differentiate between praise and feedback. Clearly, praise always provides feedback, yet not all feedback might be praise. To put it simply, when giving praise statements, teachers inform students about the condition of the answer which is acceptable or not. If commenting "okay", "all right", "correct" or giving a letter grade or percentage score, teachers are providing feedback not the praise. Besides, praise sounds more personal than feedback in the sense that praise expresses positive teacher emotions such as surprise, pleasurability, excitement, admiration and/or places the student's behaviour in context by giving information about its value or its implication about the student's status. Thus, praise is " $a$ form of feedback that conveys information about the correctness or appropriateness of answers and other behaviours, as well as information about the teacher's positive regard for the behaviours" [12, p. 32].

Effort praise concentrates on the effort or specific strategy students use to complete a task, thus noticing the essence and merit of an accomplishment [13], such as "Wow! You did great! You must have worked hard on this." Ability praise - trait-oriented or person praise - appreciates work only as a reflection of ability [14], like "Wow! You did well on this task! You are very smart," would be an illustration of this type of praise. General praise is directed either at no one in particular or an individual, it is generic in its use, for example "Great job, class!" or "Well done, Tonny." General praise lacks credibility because it takes no effort at all for a praiser to give a compliment without having paid any attention to the performance of people, whereas specific praise focuses on an individual student and very specific information or descriptive feedback [15], such as "Great job explaining absolute value, John". Thus, specific praise informs students about not only their correction, but also meaningfulness. Verbal praise occurs when the teacher follows a student action or response with some type of positive comment [16] such as "Good," or "That's right", while non-verbal praise refers to the use of some physical action to send a message of approval for some student actions or responses as "thumb-up" or $O K$ signs.

As noted from the other studies in this field, not many studies have been carried out the 6 kinds of teacher praise at the tertiary level. From the findings of this research, some implications for teaching and learning would be proposed to harvest the fruits of teaching and learning to meet the expectations of both educators and students. 


\section{Method}

The study employed the descriptive statistics by combining both quantitative and qualitative methods in terms of classroom observation and semi-structured interview to obtain the data. As clearly stated by Allwright \& Bailey [17], observation is a form of "naturalistic inquiry", which is adopted to investigate what really happens in a classroom. In order to give insights into the students' perception of teacher praise, semi-structured interviews were conducted with praised students. The choice of semi-structured rather than structured interview was employed because it offered sufficient flexibility to approach different respondents differently while still covering the same areas of data collection [18]. After each observation session, the praised students participated in the interview with the specified questions based on the framework of students' perception, specifically their cognitive (self-awareness), affective (preference) and conative (motivation to study).

\subsection{Participants}

The studied comprised of 50 third-year students and 5 instructors from 3 universities in Hanoi, namely Hanoi Law University, Foreign Trade University, and National Academy of Public Administration. The students involved in 6 male participants (12\%) and 44 female respondents ( $88 \%$ ). $46 \%$ came from urban areas and 54\% from rural living. They had studied English for seven years in secondary schools, and for two years as university students. As juniors, they were familiar with the teaching style of their teachers, and were active and cooperative with their classmates as well. After classroom observation sessions, the total number of the praised students was 30 . They were treated as the subjects of the interviews. Four of them $(13.3 \%)$ were male and twenty-six $(86.7 \%)$ were female. In terms of GPA, these students could be divided into two groups; highachievers (63.3\%) and low-achievers (36.7\%).
Besides, two female and three male teachers who were in charge of teaching the third year students took part in this research. They were all aged from 25 to 45 . They had a minimum of three-year teaching experience and a maximum of 23 years of that.

\subsection{Procedures}

Data collection during the observation period lasted 4 weeks. Data were collected in each of 5 lecturers, resulting from a total of 20 class visits (each visit - 45 minutes/lesson) thanks to classroom activities such as lecture-giving, tutorials, exercise-checking and students' presentation. They also ranged from individual seatwork to entire class oral discourse. Each observation session lasted 50 minutes. During observation procedure, the students' names who earned teacher praise and the statements of teacher praise or any other accompanying factors were noted. After each observation session, these students were invited to join in semi-structured interviews with 10 prepared questions. Finally, the two sources of information were studied correlatively so that a thorough understanding of the students' perception of teacher praise was compromised and presented. Based on the notes from observation forms, the types of praise were found out with the number of occurrence, mean, standard deviation, and the students for semi-structured interviews were selected.

\section{Results and Discussions}

\subsection{Different types of teacher praise}

Table 1. The presentation of different types

\begin{tabular}{ccccc}
\multicolumn{5}{c}{ of teacher praise } \\
\hline No. & $\begin{array}{c}\text { Type of } \\
\text { praise }\end{array}$ & $\begin{array}{c}\text { Times of } \\
\text { occurrence }\end{array}$ & Mean & $\begin{array}{c}\text { Standard } \\
\text { Deviation }\end{array}$ \\
\hline 1 & Effort & 10 & 2.0 & 0.7 \\
2 & Ability & 5 & 1.0 & 1.2 \\
3 & Specific & 10 & 2.0 & 1.0 \\
4 & General & 20 & 4.0 & 2.0 \\
5 & Verbal & 28 & 5.6 & 2.3 \\
6 & Non- & 14 & 2.8 & 1.9 \\
\hline
\end{tabular}


The total number of praise given was 30 , among which mean frequencies were computed for each type of praise as shown in Table 1.

As glimpsed from Table 2, not much difference in the times of occurrence between the four types of praise namely non-verbal $(2.8 \%)$, effort \& specific ( $2.0 \%$ equally), and ability $(1.0 \%)$. On the other hand, there were statistically great discrepancies in the appearance of specific versus general praise, verbal versus non-verbal praise. As noted during the class observation, effort praise was delivered when the teachers appreciated students for their successful or brave attempt, and task fulfillment. Such illustrations were Good attempt, Well-done. Congratulations!, or Your best effort. Meanwhile, ability praise was given in the case of intelligence or competence of the students, such as Very smart!, That's good!, ... General praise could be such one- or two-word compliments as Good job!, Very good or structured in That's + adjective!. In contrast, specific praise tended to be longer and varied in structures. It is also noticeable that very few number of non-verbal praise went alone. Often such non-verbal praise as nodding, smiling or thumb-up sign was integrated with verbal praise, but not vice versa. During the observation process, it was interesting to recognize that rate and types of praise seemed to depend on not only student behaviour or performance but also the teacher's personality, teaching style, and kind of activities that teachers carried out in the classroom settings.

\subsection{Students' preference for different types of teacher praise}

Table 2 presented the students' preference for different types of praise with regard to students' inclination to the three dimensions of praise.

In terms of effort praise and ability, there was not very different. As for the preference for ability praise, $46.7 \%$ of respondents was grouped while $53.3 \%$ preferred effort praise because of their liking for hard work or strategies for task fulfillment with a hope of being acknowledged. This fact was opposite to the finding by Burnett (2001) [19] with effort praise $(84 \%)$ and ability praise (16\%). In short, these facets of praise would not influence a university student in Vietnam the same way in comparison with younger students. When considering general praise versus specific praise, the finding showed that clear explanation and constructive feedback in the specific praise helped students build their confidence as the possibility of misunderstanding was somehow avoided. The finding revealed that specific praise earned $70 \%$ and general praise $30 \%$. This result was similar to that of Bear [20], \& Robins [21]. When compared between verbal and nonverbal praises, the discrepancies were quite remarkable. Most students preferred the detailed praises - verbal praise $(86.7 \%$ instead of non-verbal praise $(13.3 \%)$. This finding was quite different from Bani [22], which claimed that non-verbal praise could serve as positive intervention instrument and impact on children's behavior.

Table 2. Students' preference for different types of teacher praise

\begin{tabular}{cc}
\hline Types of teacher praise & $\begin{array}{c}\text { Students' preference } \\
\text { (in percentage) }\end{array}$ \\
\hline Effort & $53.3 \%$ \\
Ability & $46.7 \%$ \\
Specific & $70.0 \%$ \\
General & $30.0 \%$ \\
Verbal & $86.7 \%$ \\
Non - verbal & $13.3 \%$ \\
\hline
\end{tabular}

\subsection{High-achievers versus low-achievers in} preference for teacher praise

The data presented in the table 3 below was the result of 20 class visits with the uneven praises from teachers for 19 high achievers and 11 low ones. There were quite differences in the figures here. This data showed that high-achievers $(63.2 \%$ for ability) wanted to prove their intelligence, their capability which in turn inspired them to higher levels of 
challenge. Whereas, low-achievers expected to receive teacher praise for their hard work, skills and strategies for given task fulfillment that led them to increase attempt and enhance skills even the mistakes in the learning process $(81.8 \%$ for effort).

Table 3. The comparison between high-achievers' and low-achievers' preference for teacher praise

\begin{tabular}{ccc}
\hline $\begin{array}{c}\text { Types of } \\
\text { teacher } \\
\text { praise }\end{array}$ & $\begin{array}{c}\text { High-achievers' } \\
\text { preference } \\
\text { (in percentage) }\end{array}$ & $\begin{array}{c}\text { Low-achievers' } \\
\text { preference } \\
\text { (in percentage) }\end{array}$ \\
\hline Effort & $36.8 \%$ & $81.8 \%$ \\
Ability & $63.2 \%$ & $18.2 \%$ \\
Specific & $68.4 \%$ & $27.3 \%$ \\
General & $31.6 \%$ & $72.7 \%$ \\
Verbal & $84.2 \%$ & $90.9 \%$ \\
Non- verbal & $15.8 \%$ & $9.1 \%$ \\
\hline
\end{tabular}

\section{Conclusion}

Teacher praise creates a worthy atmosphere where students feel supported and appreciated, it is also regarded as a classroom communicative reinforce device in motivating students to be active in the learning process. In this study, university students perceived verbal and specific praises in a more motivating way than the other types because of their apparent recognition and accurate information about their performance which was given by their teachers during the course of the lesson. Among six types of teacher praise, specific praise could influence better students' selfconcept because it helped them value what they had performed. The perception of praise was also different between high-achievers and low-achievers in that high achievers preferred ability praise while low achievers desired effort praise. From these findings, teachers should choose the best strategies and use their praises flexibly for different students. In summary, it is advisable for teachers to know how to understand and compromise different students' learning styles in the classroom to create a more equitable and satisfying learning settings for all students to do their best.

\section{Implications}

To cultivate the teaching skills, teachers need to master their praises for different groups of multi-level students in the classroom. From the finding of this research, it can be said that praise is an essential and inseparable device in teaching and learning process. Thus, the more teachers use the correct praise for different groups of students, the more students perceive in terms of proud feeling, happiness and satisfaction, and motivation.

It is advisable for teachers to use their praise wisely. In fact, students come from different socio-economic status families, and have different individual traits, social and cultural background, they should be categorized to receive suitable teacher praise. In practice, effective praise should be sincere, fair and sensitive to students' preferences. To do this effectively, teachers should use apply distinctive and diverse praises on their students' learning styles.

This study sheds light on the fact that praise is regarded as a reinforce which stimulates the recipients of teacher praise to promote that actions more and more. In fact, being noticed and appreciated for having done some right, students are active to involve and commit to participate in the learning activities.

\section{REFERENCES}

[1]. J. H. Corpus and M. R. Lepper, "The effects of person versus performance praise on children's motivation: Gender and age as moderating factors," Educational psychology, vol. 27, no. 4, pp. 487-508, 2007, doi: $10.1080 / 01443410601159852$.

[2]. C. Sansone and J. M. Harackiewicz, Intrinsic and extrinsic motivation: The search for optimal motivation and performance. San Diego, CA, US: Academic Press, 2000.

[3]. M. A. Stormont, S. C. Smith and T. J. Lewis, "Teacher implementation of precorrection and praise statements in Head Start classrooms as a component of a program-wide system of positive behavior support," Journal of Behavioral Education, vol. 16, no. 3, pp. 280290, 2007, doi: 10.1007/s10864-007-9040-3. 
[4]. R. Vollmeyer and F. Rheinberg, "A surprising effect of feedback on learning," Learning and Instruction, vol. 15, no. 6, pp. 589-602, 2005, doi:10.1016/j.learninstruc.2005.08.001.

[5]. D. Rachman and D. R. Nur, "The Relationship between English Teacher's Praise and English Learning Achievement of The Tenth Grade of SMK Negeri 9 Samarinda," JELE (Journal of English Language and Education), vol. 3, no. 1, pp. 54-62, 2017, doi:10.26486/jele.v3i1.242.

[6]. J. Henderlong and M. R. Lepper, "The effects of praise on children's intrinsic motivation: A review and synthesis," Psychological bulletin, vol. 128, no. 5, pp. 774-795, 2002, doi:10.1037/0033-2909.128.5.774

[7]. A. Driscoll and R. Hitz, "Praise in the classroom," ERIC Clearinghouse on Elementary and Early Childhood Education Urbana IL, pp. 1-6, 1989. [Online]. Available: https://files.eric.ed.gov/fulltext/ED313108.pdf. [Accessed Oct. 15, 2019]

[8]. R. P. Trussell, "Classroom universals to prevent problem behaviors," Intervention in School and Clinic, vol. 43, no. 3, pp. 179-185, 2008, doi:10.1177/1053451207311678.

[9]. E. L. Duchaine, K. Jolivette and L. D. Fredrick, "The effect of teacher coaching with performance feedback on behavior-specific praise in inclusion classrooms," Education and Treatment of Children, vol. 34, no. 2, pp. 209-227, 2011. [Online]. Available: http://w ww.jstor.org/stable/. [Accessed Oct. 15, 2019].

[10]. Oxford Advanced Learner's Dictionary $9^{\text {th }}$ edition, 2015. [Online]. Available: https://www .oxfordlearnersdictionaries.com/definition/eng lish/praise_1?q=praise. [Accessed Oct. 15, 2019].

[11]. L. Canter and M. Canter, "Assertive discipline: positive behavior management for today's schools," Santa Monica, CA: Lee Canter ve Associates, 1992. [Online]. Available: https://faculty.washington.edu/dch eney/EDSPE503ClassroomManagement/Read ings/CanterChapter.pdf. [Accessed Oct. 15, 2019].

[12]. E. T. Emmer, "Praise and the instructional process," Journal of Classroom Interaction, vol. 23, pp. 32-39, 1998. [Online]. Available: http://www.jstor.org/stable/23869257. [Accessed Oct.15, 2019].

[13]. D. C. Molden and C. S. Dweck, "Meaning and motivation," in Intrinsic and extrinsic motivation: The search for optimal motivation and performance, C. Sansone \& J. M.
Harackiewicz (Eds.), San Diego, CA, US: Academic Press, pp. 131-159, 2000, doi:10.1016/B978-012619070-0/50028-3.

[14]. S. Xing, X. Gao, Y. Jiang, M. Archer and X. Liu, "Effects of Ability and Effort Praise on Children's Failure Attribution, SelfHandicapping, and Performance," Front Psychol, vol. 9, no. 1883, pp. 1-9, 2018, doi: 10.3389/fpsyg.2018.01883.

[15]. M. Ferguson, "Praise: What Does the Literature Say? What Are the Implications for Teachers?" Kairaranga, vol. 14, no. 2, pp. 3539, 2013. [Online]. Available: https://files .eric.ed.gov/fulltext/EJ1025643.pdf.

[Accessed Oct. 15, 2019].

[16]. L. J. Cooper, D. P. Wacker, D. Thursby, L. A. Plagmann, J. Harding, T. Millard, and M. Derby, "Analysis of the effects of task preferences, task demands, and adult attention on child behavior in outpatient and classroom settings," Journal of Applied Behavior Analysis, vol. 25, no. 4, pp. 823-840, 1992, doi:10.1901/jaba.1992.25-823.

[17]. R. Allwright, D. Allwright and K. M. Bailey, Focus on the language classroom: An introduction to classroom research for language teachers, Cambridge University Press, 1991. [Online]. Available: https://eric.ed.gov/?id= ED363138. [Accessed Oct. 15, 2019].

[18]. Z. Anja, "Difference between structured, unstructured and semi-structured job interviews," 2018. [Online]. Available: https://www.talentlyft.com/en/blog/article/92/ difference-between-structured-unstructuredand-semi-structured-job-interviews. [Accessed Oct. 15, 2019].

[19]. P. C. Burnett, "Elementary students' preference for teacher praise," Journal of Classroom Interaction, vol. 36, no. 1, pp. 1623, 2001. [Online]. Available: http://www. jstor.org/stable/23870540. [Accessed Oct. 15, 2019].

[20]. G. G. Bear, The Guilford practical intervention in the school series. School discipline and selfdiscipline: A practical guide to promoting prosocial student behavior. US: Guilford Press, New York, 2010.

[21]. G. Robins, Praise, motivation and the child. Routledge, 2012, doi:10.4324/9780203117682.

[22]. M. Bani, "The use and frequency of verbal and non-verbal praise in nurture groups," Emotional and Behavioral Difficulties, vol. 16, no. 1, pp. 47-67, 2011, doi: $10.1080 / 13632752.2011 .54564$. 